\title{
OPEN Armillaria root rot fungi host single-stranded RNA viruses
}

\author{
Riikka Linnakoski1,5, Suvi Sutela1,5, Martin P. A. Coetzee'2, Tuan A. Duong ${ }^{2}$, Igor N. Pavlov ${ }^{3,4}$, \\ Yulia A. Litovka ${ }^{3,4}$, Jarkko Hantula ${ }^{1}$, Brenda D. Wingfield ${ }^{2}$ \& Eeva J. Vainio ${ }^{1 凶}$
}

Species of Armillaria are distributed globally and include some of the most important pathogens of forest and ornamental trees. Some of them form large long-living clones that are considered as one of the largest organisms on earth and are capable of long-range spore-mediated transfer as well as vegetative spread by drought-resistant hyphal cords called rhizomorphs. However, the virus community infecting these species has remained unknown. In this study we used dsRNA screening and high-throughput sequencing to search for possible virus infections in a collection of Armillaria isolates representing three different species: Armillaria mellea from South Africa, A. borealis from Finland and Russia (Siberia) and $A$. cepistipes from Finland. Our analysis revealed the presence of both negativesense RNA viruses and positive-sense RNA viruses, while no dsRNA viruses were detected. The viruses included putative new members of virus families Mymonaviridae, Botourmiaviridae and Virgaviridae and members of a recently discovered virus group tentatively named "ambiviruses" with ambisense bicistronic genomic organization. We demonstrated that Armillaria isolates can be cured of viruses by thermal treatment, which enables the examination of virus effects on host growth and phenotype using isogenic virus-infected and virus-free strains.

The fungal genus Armillaria (Fr.) Staude includes more than 40 described species ${ }^{1}$. They are mainly known as notorious plant pathogens of managed natural forests and plantations of non-native tree species that infect hundreds of different plants, including economically important conifers (e.g. Abies, Picea, Pinus) and agronomic plants (e.g. Citrus, Juglans, Malus, Prunus, Vitis) ${ }^{2}$. Most Armillaria species are facultative necrotrophs capable of colonizing living roots, killing root tissues and utilizing dead wood as their source of nutrition. Some species produce edible fruiting bodies, generally known as honey mushrooms. Vegetative diploid individuals (clones) of A. ostoyae and A. gallica are amongst the largest and oldest organisms on earth, and single clones have been estimated to occupy up to 965 ha and be $1900-8650$ years of age ${ }^{3-6}$.

In Europe, the two Armillaria lineages causing most damage to trees and woody plants are A. mellea and A. solidipes/ostoya $e^{5}$, both of which have very broad host ranges ${ }^{7}$. The A. mellea lineage has a transcontinental distribution in Europe, North America, Asia and Middle East, and it also occurs as an alien species after being introduced by human activities beyond its natural distribution range. This fungus was introduced into South Africa by the Dutch settlers more than 300 years ago ${ }^{8}$ and has escaped from the planted environment to the sensitive and ecologically important natural woody habitat of the surrounding Table Mountain ${ }^{9}$. In central and northern Europe, A. ostoyae occurs sympatrically with A. borealis and A. cepistipes (syn. A. lutea). A. gallica is also native to the northern hemisphere (North America, Europe and Japan), where it is considered as a weak pathogen ${ }^{10-12}$. The species also occurs in Kirstenbosch Botanical Gardens in South Africa, presumably being introduced in the country from Asia.

Agricultural crops may be protected against Armillaria diseases by root collar excavation or chemical pesticides. Stump removal has been shown as an effective method for controlling A. ostoyae in the boreal forest region $^{13}$. However, none of the methods that are presently used can fully eradicate an established Armillaria mycelium from a contaminated site.

Fungal viruses (mycoviruses) infect hosts representing diverse fungal taxa and various lifestyles including ascomycetous and basidiomycetous micro- and macrofungi, as well as early-diverging fungal lineages such as Chytridiomycota, Blastocladiomycota, Neocallimastigomycota, Zoopagomycota and Mucoromycota ${ }^{14-17}$. They are also commonly found in edible mushrooms like the cultivated button mushroom (Agaricus bisporus) and

\footnotetext{
${ }^{1}$ Natural Resources Institute Finland (Luke), Helsinki, Finland. ${ }^{2}$ Department of Biochemistry, Genetics and Microbiology, Forestry and Agricultural Biotechnology Institute (FABI), University of Pretoria, Pretoria, South Africa. ${ }^{3}$ Laboratory of Reforestation, Mycology and Plant Pathology, V.N. Sukachev Institute of Forest SB RAS, Krasnoyarsk, Russia. ${ }^{4}$ Department of Chemical Technology of Wood and Biotechnology, Reshetnev Siberian State University of Science and Technology, Krasnoyarsk, Russia. ${ }^{5}$ These authors contributed equally: Riikka Linnakoski and Suvi Sutela. ${ }^{凶}$ email: eeva.vainio@luke.fi
} 
the shiitake (Lentinula edodes) as well as true truffles (Tuber spp. $)^{18-20}$. On the other hand, root rot pathogens such as Heterobasidion spp. infecting conifers and the white root rot fungus Rosellinia necatrix infecting fruit trees have been extensively investigated for the occurrence of mycoviruse ${ }^{21-23}$ in attempts to find viruses suitable for biological control. However, currently the only mycoviral biocontrol agent used in field conditions is the hypovirus CHV1 that significantly reduces the pathogenicity of the ascomycetous Chestnut blight fungus (Cryphonectria parasitica) in Europe $e^{24,25}$.

Our understanding of the virosphere has recently been revolutionized by high-throughput sequencing (HTS) studies, which have revealed many novel viruses representing yet unassigned virus groups related to but phylogenetically distinct from classified members of the orders Bunyavirales, Serpentovirales, Hepelivirales, Martellivirales, Tolivirales and Tymovirales, many of which have traditionally known to include only viruses that infect animals or plants (https://talk.ictvonline.org/ictv-reports/ictv_online_report/). Furthermore, metagenomic studies have revealed the common occurrence of newly discovered evolutionary lineages of mycoviruses, such as the viral family Mymonaviridae in order Mononegavirales ${ }^{26}$, the viral family Botourmiaviridae in order Ourlivirales ${ }^{27}$, and the unclassified virus group tentatively named "ambiviruses"28,29.

Despite their importance as forest and agricultural pathogens, viruses of Armillaria spp. have not been molecularly characterized prior to this study. Early studies by Blattny ${ }^{30}$ and Reaves et al. ${ }^{31}$ reported the occurrence of virus-like particles in A. mellea and A. ostoyae, but these studies were not followed by viral genome sequence characterization. In this study, we used cellulose chromatography and HTS (RNA-Seq) complemented with Sanger sequencing to investigate the occurrence of virus infections in isolates of A. mellea and A. gallica from South Africa, A. borealis from Finland and Siberia and A. cepistipes from Finland. In addition, we examined transcriptomic datasets of 12 Armillaria species available in GenBank for the presence of viruses using the same bioinformatics pipeline.

\section{Results}

Virus detection. Initially, we selected 63 Armillaria strains for dsRNA virus screening (see Supplementary Table S1 online). The cellulose chromatography analysis did not reveal any clear dsRNA elements in the Armillaria isolates, whereas the partitiviruses hosted by the Heterobasidion isolates used as control were detected in every assay. Only a very faint fragment of ca. $2 \mathrm{~kb}$ was observed in A. borealis N40 (data not shown). For this reason, we employed an RNA-Seq approach as an alternative virus detection strategy as it enables the detection all viruses with RNA genomes as well as transcribed DNA viruses. Nine Armillaria strains from three different geographical regions (Finland, Russia and South Africa) and three host species (A. borealis, A. cepistipes and A. mellea) were included in the analysis. The RNA-Seq library of $\sim 130$ million paired-end reads can be accessed through the BioProject accession number PRJNA685612 in the SRA archive of NCBI.

The de novo contig assembly using Trinity produced a total of 187,685 contigs, of which 64 (see Supplementary Table S2 online) showed sequence similarity with known viruses. Further sequence analysis revealed that they represented seven distinct viruses, some of which were observed in more than one host isolate (Table 1). No amplification was obtained from DNA templates indicating that none of the viruses were integrated into the host genome. Two ORFan contigs (contigs with long ORFs without detectable sequence identity with any known proteins), representing the same sequence, were detected with the criteria used for identification (see Supplementary Table S3 online). None of the viral genomes were $2 \mathrm{~kb}$ in size.

Publicly available transcriptomic datasets for 13 Armillaria isolates representing 12 Armillaria species (see Supplementary Table S4 online) were analysed. Three putative viruses were discovered in RNA-Seq libraries of A. mellea, and one each in A. ectypa, A. luteobubalina and A. novae-zelandiae (Table 1).

Virus genome characterization and taxonomical assignment. Sequence characteristics of a new virga-like virus from a Siberian strain of A. borealis. Two nearly identical Trinity contigs shared the highest Blastx similarity with virga-like viruses (see Supplementary Table S5 online). They represented a new virus found to be hosted by A. borealis strain N40 and designated as Armillaria borealis mycovirgavirus 1 (AbMV1). The 5' and 3' untranslated region (UTR) sequences of AbMV1 were determined with Sanger sequencing, resulting in a complete genome sequence of 11,238 nt without the poly(A) tail and four predicted ORFs (Table 1; Fig. 1A,B). Mapping of reads (Table 1) and variant calling using Geneious R10 revealed the sequence to be nearly invariable with only three polymorphic nucleotide sites (see Supplementary Table S6 online). Based on Blastx analysis of the complete genome sequence, the closest relative of AbMV1 was Auricularia heimuer mycovirgavirus 1 (AhMV1, Martellivirales; unclassified Virgaviridae) from China ${ }^{32}$. The $5^{\prime}$ UTR of AbMV1 includes repeat sequences of UUCCA and UUCAA, which resemble those of the AhMV1. The largest ORF was predicted to encode a replication protein (predicted $\mathrm{M}_{\mathrm{r}}=272.504 \mathrm{kDa}$ ) including an RNA-dependent RNA polymerase (RdRP) domain, a methyltransferase and a helicase (Fig. 1B). The third ORF encodes a protein (predicted $\mathrm{M}_{\mathrm{r}}=75.310 \mathrm{kDa}$ ) homologous to virgavirus movement proteins (MPs), and the fourth ORF resembles a coat protein (predicted $\mathrm{M}_{\mathrm{r}}=34.078 \mathrm{kDa}$ ) similar to those in AhMV1. Interestingly, the second ORF showed some homology with the protease domains of Setosphaeria turcica hypovirus 1 and Phomopsis longicolla hypovirus (GenBank accessions AZT88613 and AIG94930). A recombination event between distantly related viruses (a dsRNA megabirnavirus and a positive-sense ssRNA hypovirus) has been reported earlier by Wang et al. ${ }^{33}$.

Phylogenetic analysis revealed that AbMV1 forms a highly supported cluster with other virga-like viruses from asco- and basidiomycetous fungi (Fig. 2). A separate cluster with unclassified virga-like viruses included Entomophthora virgavirus A (GenBank accession MK231110, unpublished) from a basal fungus (subkingdom Zoopagomyceta) and several viruses obtained from insect metatranscriptomic studies. 


\begin{tabular}{|c|c|c|c|c|c|c|c|c|c|c|c|c|c|c|}
\hline Mycovirus & Abbreviation & GenBank ID & BioProject ID & SRA run & Reference & $\begin{array}{l}\text { Armillaria } \\
\text { host strain }\end{array}$ & $\begin{array}{l}\text { Length } \\
\text { (nt) }\end{array}$ & $\begin{array}{l}\text { G+C } \\
\text { content }\end{array}$ & $\begin{array}{l}\text { Mapping } \\
\text { reads }^{a}\end{array}$ & $\begin{array}{l}\text { Average } \\
\text { depth }^{b}\end{array}$ & $\begin{array}{l}\text { Virus with } \\
\text { highest Blastx } \\
\text { identity }{ }^{c}\end{array}$ & Identity & $\begin{array}{l}\text { Query } \\
\text { cover }\end{array}$ & e-value \\
\hline $\begin{array}{l}\text { Armillaria } \\
\text { borealis } \\
\text { mycovirgavi- } \\
\text { rus 1 }\end{array}$ & AbMV1 & MW423800 & \multirow{7}{*}{ PRJNA685612 } & \multirow{7}{*}{ SRR13259820 } & \multirow{7}{*}{ This study } & $\begin{array}{l}\text { A. borealis } \\
\mathrm{N} 40\end{array}$ & $11,238^{\mathrm{d}}$ & $43.5 \%$ & $38,686^{\mathrm{d}}$ & $344^{\mathrm{d}}$ & $\begin{array}{l}\text { Auricularia } \\
\text { heimuer myco- } \\
\text { virgavirus } 1^{32}\end{array}$ & $35 \%$ & $52 \%$ & 0 \\
\hline $\begin{array}{l}\text { Armillaria } \\
\text { mellea nega- } \\
\text { tive strand } \\
\text { RNA virus } 1\end{array}$ & AmNSRV1 & MW423801 & & & & $\begin{array}{l}\text { A. mellea } \\
\text { CMW3973 }\end{array}$ & 10,812 & $55.1 \%$ & 35,990 & 336 & \begin{tabular}{|l|} 
Lentinula \\
edodes \\
negative strand \\
RNA virus $1^{20}$ \\
\end{tabular} & $35 \%$ & $52 \%$ & 0 \\
\hline $\begin{array}{l}\text { Armillaria } \\
\text { mellea } \\
\text { ourmia-like } \\
\text { virus 1 }\end{array}$ & AmOlV1 & MW423802 & & & & $\begin{array}{l}\text { A. mellea } \\
\text { CMW50256 }\end{array}$ & 3,919 & $53.8 \%$ & 14,080 & 348 & $\begin{array}{l}\text { Agaricus } \\
\text { bisporus virus } \\
15^{35}\end{array}$ & $37 \%$ & $41 \%$ & le-95 \\
\hline $\begin{array}{l}\text { Armillaria } \\
\text { mellea } \\
\text { ourmia-like } \\
\text { virus 2 }\end{array}$ & AmOlV2 & MW423803 & & & & $\begin{array}{l}\text { A. mellea } \\
\text { CMW3973 }\end{array}$ & 3,162 & $47.4 \%$ & 183,835 & 5718 & $\begin{array}{l}\text { Apple ourmia- } \\
\text { like virus 3 } \\
\text { (QIC52830.1) }\end{array}$ & $38 \%$ & $38 \%$ & $6 e-74$ \\
\hline $\begin{array}{l}\text { Armillaria } \\
\text { borealis } \\
\text { ambi-like } \\
\text { virus 1e }^{\mathrm{e}}\end{array}$ & AbAlV1 & MW423804 & & & & $\begin{array}{l}\text { A. borealis } \\
\mathrm{N} 40\end{array}$ & 4,975 & $48.0 \%$ & $135,187 f$. & $2663 f$. & $\begin{array}{l}\text { Tulasnella } \\
\text { ambivirus } 4^{28}\end{array}$ & $30 \%$ & $95 \%$ & $5 e-73$ \\
\hline $\begin{array}{l}\text { Armillaria } \\
\text { borealis } \\
\text { ambi-like } \\
\text { virus } 2^{\mathrm{g}}\end{array}$ & AbAlV2 & MW423806 & & & & $\begin{array}{l}\text { A. borealis } \\
\mathrm{N} 40\end{array}$ & 4,529 & $49.1 \%$ & $411,654 f$. & 8880 f. & $\begin{array}{l}\text { Rhizoctonia } \\
\text { solani ambivi- } \\
\text { rus } 1^{29}\end{array}$ & $38 \%$ & $44 \%$ & $2 e-104$ \\
\hline $\begin{array}{l}\text { Armillaria } \\
\text { sp. ambi-like } \\
\text { virus } 3^{\mathrm{h}}\end{array}$ & AsAlV3 & MW423811 & & & & $\begin{array}{l}\text { A. borealis } \\
\mathrm{N} 40\end{array}$ & 4,521 & $50.6 \%$ & $144,486 f$. & $3122 \mathrm{f}$. & $\begin{array}{l}\text { Rhizoctonia } \\
\text { solani ambivi- } \\
\text { rus } 1^{29}\end{array}$ & $36 \%$ & $44 \%$ & 1e-104 \\
\hline $\begin{array}{l}\text { Armillaria } \\
\text { mellea nega- } \\
\text { tive strand } \\
\text { RNA virus } 2\end{array}$ & AmNSRV2 & $\begin{array}{l}\text { TPA: } \\
\text { BK014417 }\end{array}$ & PRJNA568830 & SRR10392772 & $\begin{array}{l}\text { JGI, } \\
\text { Francis M } \\
\text { Martinj }\end{array}$ & $\begin{array}{l}\text { A. mellea } \\
\text { ELDO17 }\end{array}$ & 11,682 & $50.2 \%$ & $484,353^{\mathrm{k}}$ & $6855^{\mathrm{k}}$ & $\begin{array}{l}\text { Bondarzewia } \\
\text { berkeleyi } \\
\text { negative- } \\
\text { strand RNA } \\
\text { virus 1 14 }\end{array}$ & $35 \%$ & $44 \%$ & 0 \\
\hline $\begin{array}{l}\text { Armillaria } \\
\text { ectypa ambi- } \\
\text { like virus } 1\end{array}$ & AeAlV1 & $\begin{array}{l}\text { TPA: } \\
\text { BK014418 }\end{array}$ & PRJNA455898 & SRR7968262 & \begin{tabular}{|l} 
JGI, \\
Francis M \\
Martin $^{j}$
\end{tabular} & $\begin{array}{l}\text { A. ectypa } \\
\text { FPL83.16 }\end{array}$ & 4,989 & $47.2 \%$ & $1,730^{1}$ & $51^{1}$ & $\begin{array}{l}\text { Ceratobasid- } \\
\text { ium ambivirus } \\
1^{28}\end{array}$ & $32 \%$ & $33 \%$ & $3 e-64$ \\
\hline $\begin{array}{l}\text { Armillaria } \\
\text { luteo- } \\
\text { bubalina } \\
\text { ambi-like } \\
\text { virus 1 }\end{array}$ & AlAlV1 & $\begin{array}{l}\text { TPA: } \\
\text { BK014419 }\end{array}$ & PRJNA455055 & SRR7777675 & $\begin{array}{l}\text { JGI, } \\
\text { Jonathan } \\
\text { M Plett' }\end{array}$ & $\begin{array}{l}\text { A. } \\
\text { luteobubalina } \\
\text { HWK02 }\end{array}$ & 4,428 & $48.8 \%$ & 5,106 & 172 & $\begin{array}{l}\text { Tulasnella } \\
\text { ambivirus } 4^{28}\end{array}$ & $31 \%$ & $40 \%$ & $6 e-73$ \\
\hline $\begin{array}{l}\text { Armillaria } \\
\text { mellea ambi- } \\
\text { like virus } 1\end{array}$ & AmAlV1 & $\begin{array}{l}\text { TPA: } \\
\text { BK014420 }\end{array}$ & PRJNA568830 & SRR10392772 & \begin{tabular}{|l} 
JGI, \\
Francis M \\
Martinj
\end{tabular} & $\begin{array}{l}\text { A. mellea } \\
\text { ELDO17 }\end{array}$ & 4,329 & $47.6 \%$ & $9,251^{k}$ & $305^{\mathrm{k}}$ & $\begin{array}{l}\text { Cryphonectria } \\
\text { parasitica } \\
\text { ambivirus } 1^{29}\end{array}$ & $29 \%$ & $40 \%$ & le-51 \\
\hline $\begin{array}{l}\text { Armillaria } \\
\text { mellea ambi- } \\
\text { like virus 2 }\end{array}$ & AmAlV2 & $\begin{array}{l}\text { TPA: } \\
\text { BK014421 }\end{array}$ & PRJNA297618 & SRR2545913 & Tsai et al. ${ }^{85}$ & A. mellea $^{\mathrm{m}}$ & 4,474 & $50.6 \%$ & 14,035 & 229 & $\begin{array}{l}\text { Rhizoctonia } \\
\text { solani ambivi- } \\
\text { rus } 1^{29}\end{array}$ & $37 \%$ & $44 \%$ & le- 104 \\
\hline $\begin{array}{l}\text { Armillaria } \\
\text { novae- } \\
\text { zelandiae } \\
\text { ambi-like } \\
\text { virus 1 }\end{array}$ & AnzAlV1 & $\begin{array}{l}\text { TPA: } \\
\text { BK014422 }\end{array}$ & PRJNA677795 & SRR13091473 & $\begin{array}{l}\text { JGI, } \\
\text { Francis M } \\
\text { Martin }\end{array}$ & $\begin{array}{l}\text { A. novae- } \\
\text { zelandiae } \\
2840\end{array}$ & 4,503 & $45.7 \%$ & 1,189 & 39 & $\begin{array}{l}\text { Tulasnella } \\
\text { ambivirus } 4^{28}\end{array}$ & $32 \%$ & $45 \%$ & $2 e-91$ \\
\hline
\end{tabular}

Table 1. Mycoviruses detected in our collection of Armillaria isolates or in transcriptomics datasets deposited in the NCBI SRA database. ${ }^{a}$ Raw reads were mapped against the virus sequence using Geneious for RNA Seq assembler with medium-low sensitivity. ${ }^{\mathrm{b}}$ Mean value generated by Geneious 10.2.6 ${ }^{\mathrm{c}}$ The sequence having highest identity with the virus based on Blastx with $\mathrm{nr}$ database. ${ }^{\mathrm{d}}$ Without poly $(\mathrm{A})$ tail. ${ }^{\mathrm{e}} \mathrm{A}$. borealis Ab9A hosted AbAlV1 variant. ${ }^{\mathrm{f}}$ Mapping with custom sensitivity using 0 as a maximum mismatch $\%$ per read. ${ }^{\mathrm{g}}$ Other A. borealis hosts of AbAlV2 were Ab2B, Ab4B, Ab9A and MUS36. ${ }^{\mathrm{h}}$ A. borealis Ab9A and A. cepistipes Al65A hosted AsAlV3 variants. ${ }^{\mathrm{i}} \mathrm{RNA}$-seq library was generated using PolyA selection. ${ }^{\mathrm{j} C o n t a c t}$ person for unpublished datasets of JGI (Joint Genome Institute). ${ }^{\mathrm{k}}$ Mapping conducted with custom sensitivity: maximum mismatch $5 \%$ per read; maximum gap $5 \%$ per read. ${ }^{1}$ Mapping conducted with custom sensitivity: maximum mismatch $1 \%$ per read; maximum gap $1 \%$ per read. ${ }^{m}$ NCBI GEO: GSM189980.

Putative mymonaviruses hosted by A. mellea from South Africa and North America. A new mymona-like virus was identified in the RNA-Seq library of A. mellea strain CMW3973 and was represented by two contigs (Table 1; Supplementary Table S5). Mapping of reads (Table 1, Fig. 1C) and variant calling using Geneious R10 revealed that the sequence was nearly invariable with only one polymorphic site (see Supplementary Table S6 online). The terminal $5^{\prime}$ and $3^{\prime}$ UTR sequences were verified by Sanger sequencing, and the virus was named Armillaria mellea negative strand RNA virus 1 (AmNSRV1, Table 1). The complete AmNSRV1 genome is 10,812 nt in length and has six predicted ORFs and $5^{\prime}$ and $3^{\prime}$ terminal UTR regions showing inverted complementarity (Fig. 1C-E). It shared the highest Blastx identity with Lentinula edodes negative strand RNA virus 1 (LeNSRV1) ${ }^{20}$ (Table 1). Furthermore, uracil-rich gene junction sequences were detected in the intergenic non-coding regions of the genomic RNA strand (Fig. 1F) as reported with LeNSRV $1^{20}$. The longest of the predicted proteins in AmNSRV1 contains the Mononegavirales RdRP conserved domain and Mononegavirales mRNA-capping region domain (Fig. 1D). Phylogenetic analysis verified that AmNSRV1 resided in a highly supported cluster together with 
A

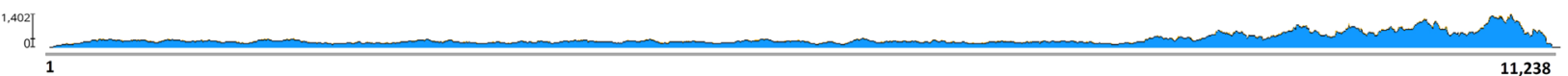

B

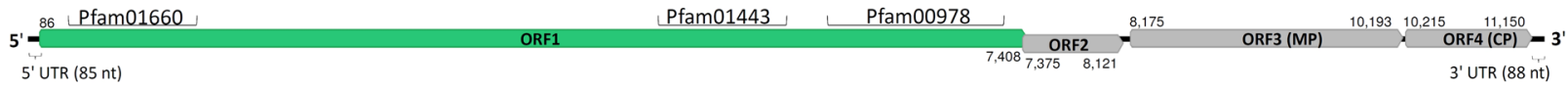

C

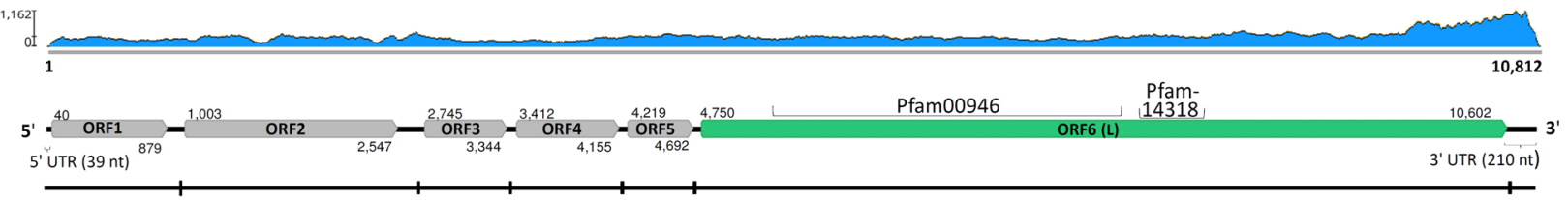

Figure 1. Genome organization of the Armillaria borealis mycovirgavirus 1 (AbMV1) and Armillaria mellea negative strand RNA virus 1 (AmNSRV1). (A) Coverage of raw reads mapped against the AbMV1 genome (without poly(A) tail). (B) Schematic presentation of AbMV1 genome with UTRs, predicted ORFs and conserved motifs: pfam00978 (RdRP domain, e-value 2.07e-72), pfam01660, (methyltransferase, e-value $1.92 \mathrm{e}-20$ ) and pfam 01443 (helicase, e-value 1.02e-24). Predicted translation initiation and termination sites are marked above or below each ORF. (C) Coverage of raw reads mapped against the AmNSRV1 genome. (D) Schematic presentation of AmNSRV1 genome with UTRs, predicted ORFs and conserved motifs: pfam00946 (Mononegavirales RdRP, e-value 1.10e-95) and pfam14318 (Mononegavirales mRNA-capping region V, e-value $4.82 \mathrm{e}-16)$. Predicted translation initiation and termination sites are marked above and below each ORF, respectively. The small vertical lines in the virus genomic segment show the location of the putative gene junction sequences. (E) Consensus sequences (uracil-rich tracts) of putative gene junction regions between the predicted ORFs in $3^{\prime}>5^{\prime}$ orientation (genomic RNA). (F) Complementarity in the $5^{\prime}$ - and $3^{\prime}$-terminal sequences in the genomic RNA strand.

LeNSRV1, the type species of proposed genus Lentimonavirus in family Mymonaviridae (Fig. 3; https://talk.ictvo nline.org/files/).

Another mymona-like virus was discovered in the SRA dataset from A. mellea ELDO17 (Supplementary Table S4). The putative viral sequence of $11,682 \mathrm{nt}$ was assembled from five Trinity contigs and had six predicted ORFs. The predicted L protein of this virus and that of AmNSRV1 shared ca. 28\% identity, while the most closely related viruses according to Blastx and Blastp searches were Bondarzewia berkeleyi negative-strand RNA virus 1 (BbNSRV1) ${ }^{34}$ and Auricularia heimuer negative-stranded RNA virus 1 (AhNSRV1, GenBank accession MT259204, unpublished) (Table 1). AhNSRV1 is the proposed representative species of the new genus Auriculariamonavirus (2020.004F.Ac.v1.Mymona at https://talk.ictvonline.org/files/). The in silico detected virus sequence was named as Armillaria mellea negative strand RNA virus 2 (AmNSRV2, Table 1).

Putative members of family Botourmiaviridae in two South African isolates of A. mellea. Two distinct ourmialike contigs were detected in isolates of $A$. mellea (see Supplementary Table S5 online). Coding complete virus genome sequences were deposited in GenBank and named Armillaria mellea ourmia-like virus 1 (AmOlV1) and Armillaria mellea ourmia-like virus 2 (AmOlV2) (Table 1). The nonsegmented genomes of AmOlV1 (3,919 nt) and AmOlV2 (3,162 nt) contain only a single predicted ORF, encoding for a putative RdRP (Fig. 4A-D), and their partial UTRs were verified using Sanger sequencing. The predicted size of the RdRP in AmOlV1 and AmOlV2 was 908 aa $\left(M_{r}=103.450 \mathrm{kDa}\right)$ and 731 aa $\left(M_{r}=81.976 \mathrm{kDa}\right)$, respectively. Based on read mapping, there were seven and five polymorphic nucleotide sites in the coding region of AmOlV1 and AmOlV2 with variant frequencies of ca. 6-30\%, respectively (see Supplementary Table S6 online).

AmOlV1 shared the highest Blastx identity with Agaricus bisporus virus $14^{35}$, and AmOlV2 with Apple ourmia-like virus 3, a magoulivirus in family Botourmiaviridae (GenBank accession QIC52830, unpublished) (Table 1). Phylogenetic analysis confirmed that AmOlV2 resembles members of genus Magoulivirus, whereas AmOlV1 clustered together with Rhizoctonia solani ourmia-like virus $1^{36}$, the proposed type species of new genus Rhizoulivirus and several unassigned ourmia-like viruses. Picarelli et al. ${ }^{37}$ suggested the existence of a separate family provisionally named "Basidionarnaviridae", encompassing the Agaricus bisporus virus $15^{35}$ and Rhizoctonia ourmia-like viruses $2-5^{37}$. The divergent grouping of the Rhizoctonia ourmia-like viruses seems to be based on their long predicted ORF regions. However, delimiting the phylogenetic analysis to the commonly shared sequence region supported the grouping of these viruses together with the proposed genus Rhizoulivirus (Fig. 5). To our knowledge, the size of the polymerase has not been experimentally determined for these viruses.

Viruses representing a new putative virus group called ambiviruses. Three distinct ambi-like viruses were retrieved from our RNA-Seq library, and were all found to be hosted by more than one Armillaria isolate (Table 1, Fig. 6A). The complete sequences of ambi-like viruses 1-3 hosted by A. borealis isolate N40 


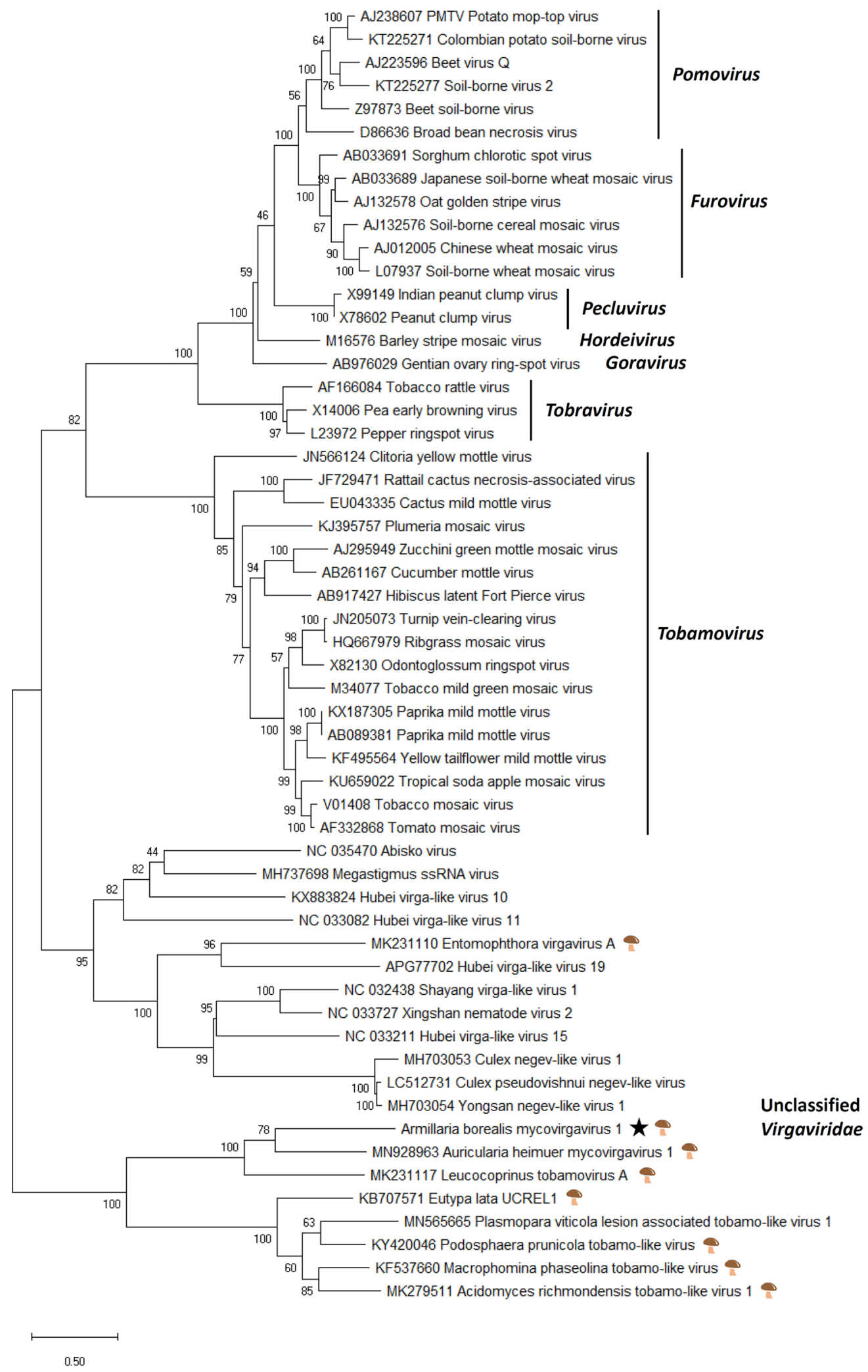

Figure 2. Phylogenetic tree of the family Virgaviridae and related unclassified viruses based on an alignment of RdRP aa sequences generated using MAFFT $v 7.450$ with Blosum 45 substitution matrix. The evolutionary history was inferred by using the Maximum Likelihood method and Le_Gascuel_2008 model with 4 gamma categories $(+G+I)$. All positions with less than $95 \%$ site coverage were eliminated, i.e., fewer than $5 \%$ alignment gaps, missing data, and ambiguous bases were allowed at any position. Evolutionary analyses were conducted in MEGA X with 1000 bootstrap repeats ${ }^{86}$. Sequences originating from fungal hosts are indicated with a mushroom symbol and a star denotes the Armillaria virus. 


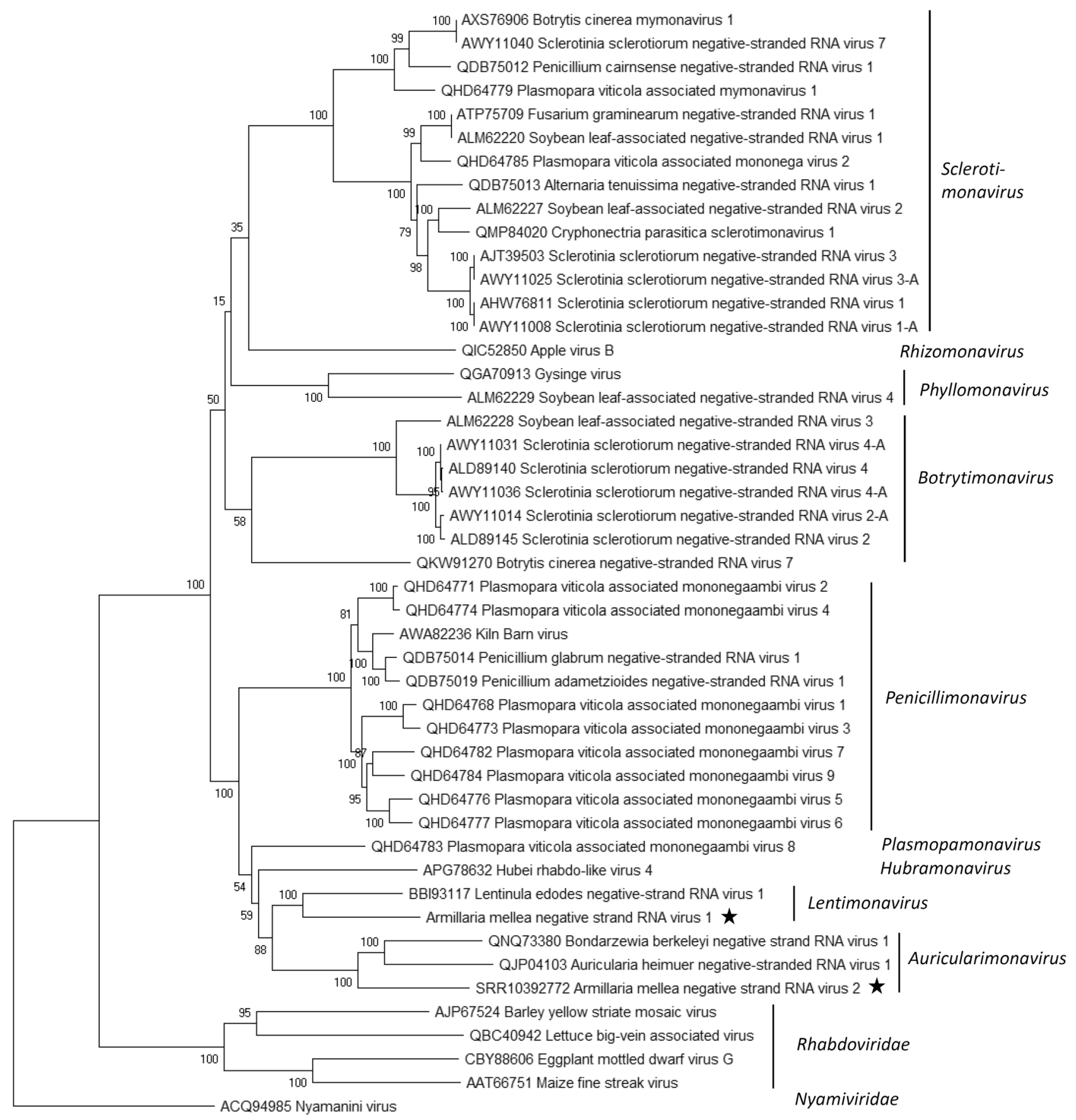

Figure 3. Phylogenetic tree of the family Mymonaviridae and selected related families based on an alignment of RdRP aa sequences generated using MAFFT $v 7.450$ with Blosum 45 substitution matrix. The evolutionary history was inferred by using the Maximum Likelihood method implemented in IQ-TREE web server multicore version 1.6.12 at http://iqtree.cibiv.univie.ac.at/ ${ }^{87}$. The best-fit model according to ModelFinder was $\mathrm{LG}+\mathrm{F}+\mathrm{I}+\mathrm{G} 4$. Bootstrapping was conducted using 1000 repetitions (ultrafast mode). The Armillaria viruses are designated with a star.

comprised 4975, 4529 and $4521 \mathrm{nt}$, each encoding for three predicted ORFs (Table 1, Fig. 4E-J). None of the predicted proteins of the viruses showed conserved domains, but the longest predicted protein of each virus included the GDD motif, which is considered as the hallmark of RdRPs. Based on the nt and aa level sequence identities (Fig. 6A), the three ambi-like viruses hosted by N40 were not considered as variants of the same virus species (although no species delimitation criteria are available for this novel group of viruses ${ }^{28,29}$ ), and were des- 
B

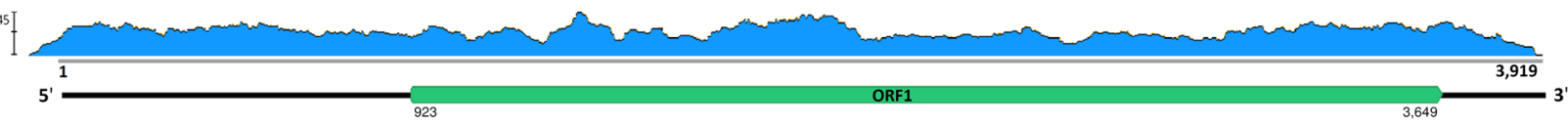

$C^{1}$

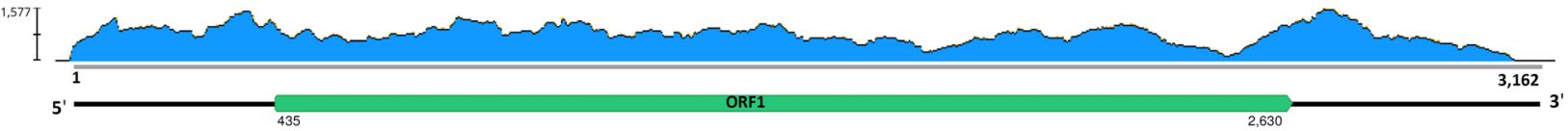

D

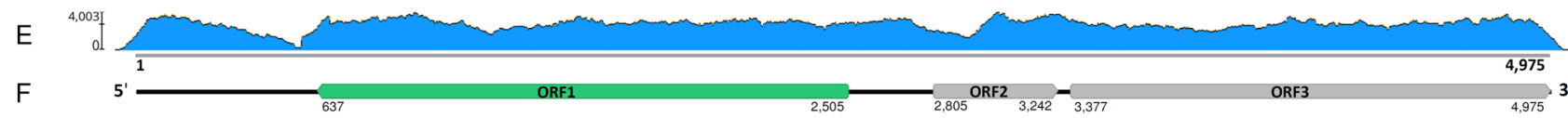

G
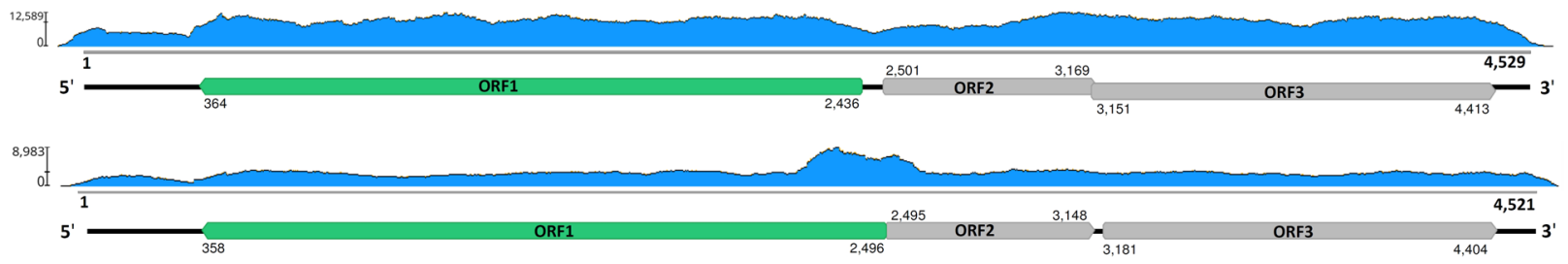

Figure 4. Genome organization of the Armillaria ourmia-like and ambi-like viruses. (A) Coverage of raw reads mapped against the Armillaria mellea ourmia-like virus 1 (AmOlV1) genome. (B) Schematic presentation of AmOlV1 genome with UTRs and predicted ORFs. (C) Coverage of raw reads mapped against the Armillaria mellea ourmia-like virus 2 (AmOlV2) genome. (D) Schematic presentation of AmOlV2 genome with UTRs and predicted ORFs. (E) Coverage of raw reads mapped against the Armillaria borealis ambi-like virus 1 (AbAlV1) genome hosted by isolate N40. (F) Schematic presentation of AbAlV1 genome with UTRs and predicted ORFs. (G) Coverage of raw reads mapped against the Armillaria borealis ambi-like virus 2 (AbAlV2) genome hosted by isolate N40. (H) Schematic presentation of AbAlV2 genome with UTRs and predicted ORFs. (I) Coverage of raw reads mapped against the Armillaria sp. ambi-like virus 3 (AsAlV3) genome hosted by isolate N40. (J) Schematic presentation of AsAlV3 genome with UTRs and predicted ORFs. Predicted translation initiation and termination sites are marked above or below each ORF. Predicted RdRPs coloured with green hue.

ignated as Armillaria borealis ambi-like virus 1 (AbAlV1), Armillaria borealis ambi-like virus 2 (AbAlV2) and Armillaria sp. ambi-like virus 3 (AsAlV3).

In addition, ambi-like viruses were discovered in five Armillaria RNA-Seq libraries deposited in the NCBI SRA database (Table 1; Supplementary Table S4; Supplementary Fig. S1; Supplementary Fig. S2). The raw reads were mapped against edited sequences of putative ambi-like viruses and were designated as Armillaria ectypa ambi-like virus 1, Armillaria luteobubalina ambi-like virus 1, Armillaria mellea ambi-like virus 1 (AmAlV1), Armillaria mellea ambi-like virus 2 (AmAlV2) and Armillaria novae-zelandiae ambi-like virus 1 (Table 1). AmAlV1 and AmAlV2 shared low sequence identities, 39.8\% at the nt level and $23.8 \%$ at the aa level when the predicted translation of longest ORFs of both putative viruses were aligned using MAFFT (see Supplementary Fig. S2 online). The number of ambi-like virus genomes is currently very limited, and little is known about their occurrence and variability. However, based on a small-scale phylogenetic analysis the ambi-like viruses of Armillaria seem to be of polyphyletic origin as they were found in separate clusters including also ambiviruses from distantly related host fungi (Fig. 6B).

Viral co-infections and interspecies divergence. All the other viruses except for the ambi-like viruses occurred in one host isolate only. However, some of them were found in mixed infections. For example, A. borealis N40 from Siberia hosted four different viruses, including the virga-like AbMV1 and three different ambilike viruses. In addition, A. mellea CMW3973 harbored the mymona-like AmNSV1 and an ourmia-like virus (AmOlV2). The RNA-Seq library of A. mellea ELDO17 (BioProject PRJNA568830) analysed in silico hosted another mymona-like virus and an ambi-like virus. Only ambi-like viruses were found in the Finnish isolates, of which A. borealis Ab9A hosted all three ambi-like viruses. The occurrence of the different ambi-like viruses in a single host isolate further supports the notion that they represent distinct virus species. This is because mutual exclusion of conspecific virus strains is considered a species delimitation criterion in many viral taxa.

Sequence variants representing a single ambi-like virus $(1,2$ or 3$)$ hosted by different $A$. borealis isolates shared more than $90 \%$ nt sequence identities (Fig. 6A), even though variation was observed in the length and genome organization between virus variants (ORF structure; Supplementary Fig. S3). Moreover, AsAlV3 showed a higher sequence identity between variants from Finland (Ab9A) and Siberia (N40) from the same host species (A. borealis) than between Finnish variants Ab9A and Al65A from two different host species (A. borealis and A. cepistipes) (Fig. 6A).

Phenotypes of virus-infected and virus-free Armillaria strains. In order to assess possible effects of viruses on the growth rate of their host, isogenic fungal strains with and without viral infections were generated using temperature treatment. Thermal treatment was successfully used to cure isolates N40, CMW3973, 


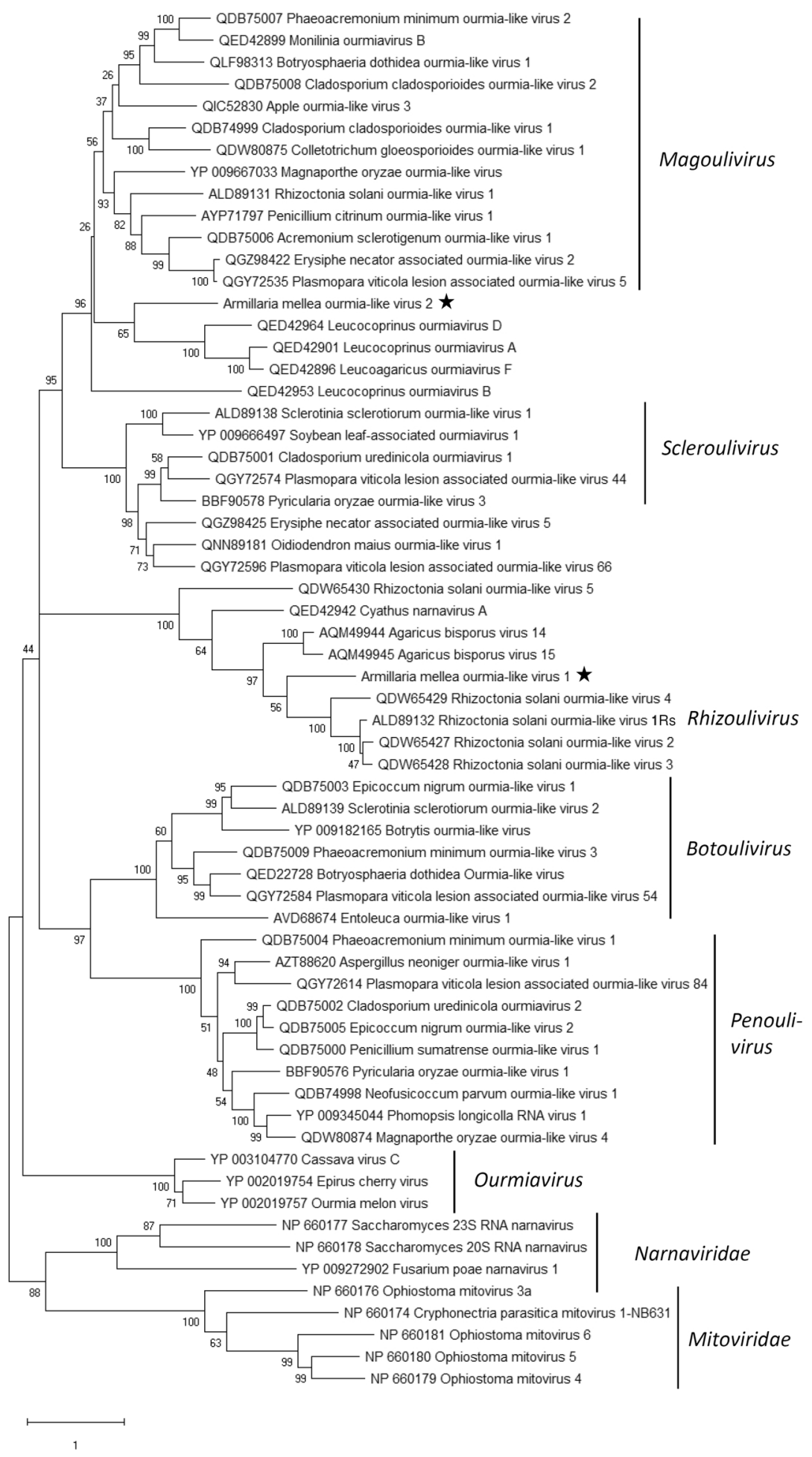

Figure 5. Phylogenetic tree of the family Botourmiaviridae and selected related families based on an alignment of RdRP aa sequences generated using MAFFT $v 7.450$ with Blosum62 substitution matrix. The evolutionary history was inferred by using the Maximum Likelihood method and Le_Gascuel_2008 model with 4 gamma categories $(+G+I)$. All positions with less than $95 \%$ site coverage were eliminated, i.e., fewer than $5 \%$ alignment gaps, missing data, and ambiguous bases were allowed at any position (partial deletion option). Evolutionary analyses were conducted in MEGA X with 1000 bootstrap repeats ${ }^{86}$. The Armillaria viruses are designated with a star. 
A

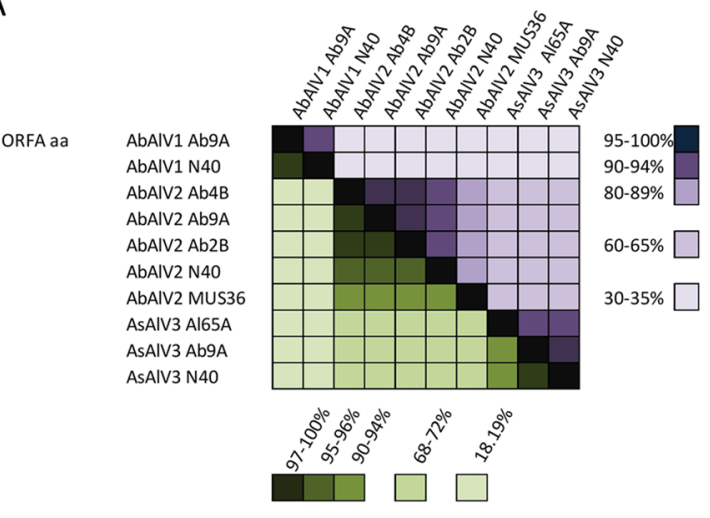

nt

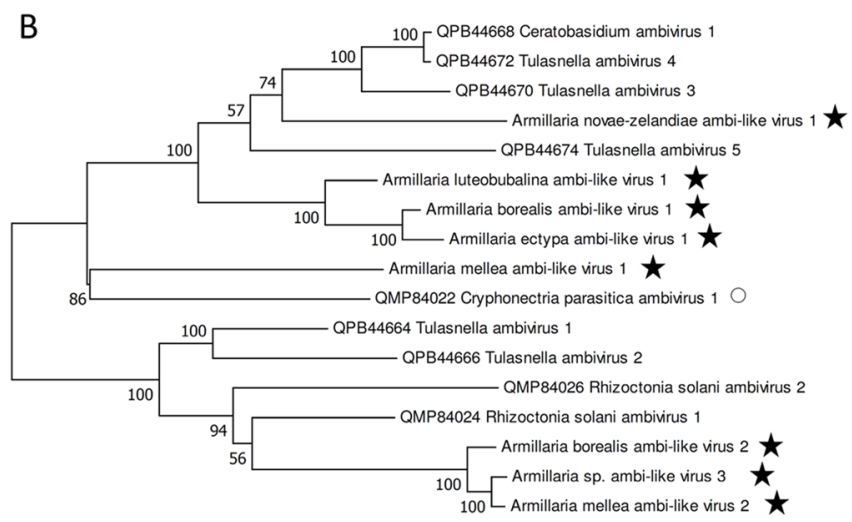

0.50

Figure 6. Pairwise identities of ambi-like viruses and phylogenetic analysis. (A) Armillaria borealis ambi-like virus 1 (AbAlV1), Armillaria borealis ambi-like virus 2 (AbAlV2) and Armillaria sp. ambi-like virus 3 (AsAlV3) hosted by Armillaria borealis isolates (Ab2B, Ab4B, Ab9A, MUS36 and N40) and A. cepistipes Al65A. Each cell presents pairwise identities between viral sequences. Alignments were generated with MAFFT in Geneious 10.2.6. Green hues represent pairwise identities between predicted RdRP aa sequences and violet hues those between complete nt sequences. (B) Phylogenetic tree of the ambi-virus like viruses was generated from predicted aa sequences of putative RdRPs aligned in MEGA $77^{88}$ with MUSCLE and using the LG $(+\mathrm{F})$ model with $\mathrm{G}+\mathrm{I}$ rates among sites (best-fit model according to ModelFinder) and 1000 bootstrap repetitions. All positions with less than 95\% site coverage were eliminated, i.e., fewer than 5\% alignment gaps, missing data, and ambiguous bases were allowed at any position. The Armillaria viruses are designated with a star. Cryphonectria parasitica ambivirus 1 is hosted by an ascomycetous host (indicated with open circle), all other ambi-like viruses have basidiomycetous hosts.

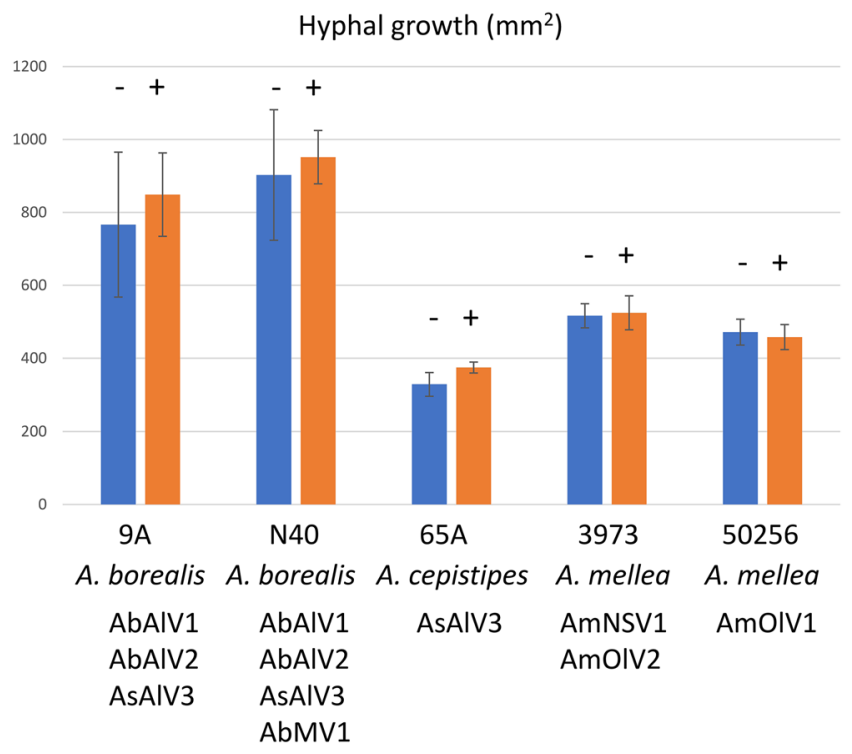

Figure 7. Growth of isogenic virus-infected and virus-free isolates of Armillaria in three weeks at $20^{\circ} \mathrm{C}$ on $2 \%$ MEA agar plates. Blue $(-)=$ thermal treated (virus-free); orange $(+)=$ virus-infected. The error bars indicate standard deviation. The t-test p-values ranged from 0.405 to 0.738 except for $65 \mathrm{~A}$ that showed a $\mathrm{p}$-value of 0.015 when comparing the isogenic strains (the growth of the virus-infected strain was on average $14 \%$ higher than that of the virus-free isogenic strain in three weeks). The number of replicate plates measured was 6 ( 4 for virusfree isolate $\mathrm{N} 40$ due to desiccation of two plates).

CMW50256, Al65A and Ab9A of viral infections. The highest incubation temperature used for the thermal treatment was $35^{\circ} \mathrm{C}$ for isolates CMW50256 and Al65A and $36^{\circ} \mathrm{C}$ for isolates N40, CMW3973 and Ab9A.

The growth rate of the original and isogenic heat-treated virus-free Armillaria strains was compared by recording their growth on $2 \%$ malt extract agar (MEA) plates during a three-week period (Fig. 7). The presence of viruses did not appear to have a major effect on the growth rate of the Armillaria isolates in laboratory conditions. 
In two cases, the hosts were originally infected with single viruses (an ambivirus or a botourmiavirus), whereas three hosts were cured of multiple virus infections (Fig. 7).

\section{Discussion}

In this study, we describe the first genome sequences of mycoviruses hosted by the notorious, globally distributed plant pathogens of genus Armillaria. These new viruses belong to the families Mymonaviridae, Botourmiaviridae and Virgaviridae as well as to a recently described virus group tentatively named "ambiviruses"28,29. Many Armillaria species and other important root-rot fungi, such as Heterobasidion spp. (Bondarzewiaceae; Basidiomycota) and Rosellinia necatrix (Xylariaceae; Ascomycota), form large and long-living clonal individuals, which can be considered as optimal targets for viral biocontrol agents. Therefore, the viromes of both Heterobasidion spp. and $R$. necatrix have been extensively studied, which has led to the discovery of numerous mycoviruses, some of which cause host debilitation ${ }^{21-23}$. Interestingly, the persistent lifestyle of these root-rot pathogens seems to lead to the accumulation of viruses in the clonal individuals (via anastomosis contacts and spores) ) $^{38,39}$ and even occasional virus transmission from other fungal species occurring in the same habitat ${ }^{40-42}$. In the case of Armillaria spp., there is no prior knowledge regarding the possible accumulation of viruses in ancient clones. Dvořák ${ }^{43}$ investigated the presence of dsRNA elements in 40 strains of A. gallica, A. cepistipes and A. ostoyae from the Czech Republic but none were detected. This is consistent with our findings that revealed only ssRNA viruses in the strains of Armillaria investigated in this study. Furthermore, only one negative-strand ssRNA virus was identified by in silico mining of transcriptomic datasets of several Armillaria species. Although more Armillaria isolates and species should be investigated for viral infections, our results showed that the virus diversity detected in Armillaria spp. is moderate compared to many other fungal species.

In this study, we identified a new virga-like virus in a Siberian strain of A. borealis. Classified members of family Virgaviridae infect plants and have rod-shaped, non-enveloped particles of about $20 \mathrm{~nm}$ in diameter and up to about $300 \mathrm{~nm}$ long $^{44}$. However, virga-like viruses have been recently described in the basidiomycete Auricularia heimuer ${ }^{32}$, the ascomycetes Macrophomina phaseolina ${ }^{36}$ and Podosphaera prunicola ${ }^{45}$ and the oomycete Plasmopara viticola (Chromalveolata, Stramenopila) ${ }^{46}$. They have also been provisionally identified by metatranscriptomic analysis in the basidiomycetous Leucocoprinus sp., and the ascomycetous Acidomyces richmondensis ${ }^{47}$ and Mycosphaerella sp. (GenBank accession MK231048, unpublished). Members of family Virgaviridae are classified in seven genera, four of which include viruses transmitted by soilborne organisms: members of the genera Furovirus, Pecluvirus, Pomovirus are vectored by plasmodiophorids (Chromalveolata, Rhizaria, Cercozoa), for example Polymyxa graminis and Spongospora subterranea, whereas members of the genus Tobravirus are transmitted by nematodes ${ }^{44}$. The vast majority of virga-like viruses found in fungi are monopartite with a similar predicted ORF structure and genome organization as plant viruses of genus Tobamovirus, which are readily transmitted mechanically but lack known vectors. However, a tripartite virga-like virus related to unclassified invertebrate-derived viruses was recently discovered in Aspergillus fumigatus ${ }^{48}$. Notably, fungal virga-like viruses appear to encode a MP, a typical feature for plant viruses but usually lacking in mycoviruses. This supports the hypothesis that fungal viruses in the class Alsuviricetes could originate from plant viruses transmitted horizontally to plant-pathogenic fungi ${ }^{49}$. However, most mycoviruses in the class Alsuviricetes seem to have lost the MP and coat protein. In contrast to plant viruses, the persistent lifestyle and intracellular mode of transmission (via porous septa within a mycelium and anastomosis contacts between mycelia) generally enables mycoviruses to be transmitted without a MP, and the genes encoding such proteins may represent evolutionary remnants in the genomes of fungal virga-like viruses ${ }^{50-52}$.

Two isolates of $A$. mellea from South Africa also hosted positive-sense RNA viruses resembling members of family Botourmiaviridae. The evolutionary history of these positive-sense RNA viruses is intriguing and appears to follow an opposite trend compared to virgaviruses that seem to have been transmitted from plants to fungi. Thus, plant viruses in the genus Ourmiavirus have a genome segment encoding an RdRP resembling those of fungal narnaviruses, another segment encoding a MP related to of plant tombusviruses, and a third genome segment encoding a $\mathrm{CP}^{27,53}$. In contrast to the plant viruses, fungal ourmia-like viruses that are currently classified in four different genera have only one genome segment encoding the RdRP. Therefore, it appears that the plant ourmiaviruses have evolved from a narnavirus that has gained the proteins encoded by the two extra genome segments from plants to be able to move between plant cell $s^{54}$. Recently, a taxonomic proposal was submitted to accommodate two new genera and 25 new species in family Botourmiaviridae (2020.001F.A.v1.Botourmiaviridae; https://talk.ictvonline.org/files/). This suggests that this previously unknown virus group is highly common among fungi. The two ourmia-like viruses in Armillaria resemble viruses found in Rhizoctonia solani that are within the genus Magoulivirus, and proposed genus Rhizoulivirus, as well as several unclassified fungal and plant botourmiaviruses. Based on criteria for the classification of members of Botourmiaviridae by the ICTV ${ }^{27}$ and virus classification guidelines in the age of metagenomics ${ }^{55}$, coding complete sequences are sufficient for the classification of new virus species.

One isolate of A. mellea from South Africa hosted a negative-strand RNA virus related to members of family Mymonaviridae. In addition, another mymona-like virus was detected in silico from a North American strain of A. mellea. As expected, based on the origin of the host isolates, the two mymona-like viruses in A. mellea were relatively distantly related. Mymonaviridae is a relatively new family of negative-sense RNA viruses that have been found only in fungi ${ }^{26}$. They have enveloped filamentous particles of $25-50 \mathrm{~nm}$ in diameter and about $1000 \mathrm{~nm}$ in length. Mymonaviruses have been found in the fungal pathogens Sclerotinia sclerotiorum and Fusarium graminearum, and the basidiomycetous wood decay fungi Lentinula edodes ${ }^{20}$ and Bondarzewia berkeleyi $i^{34}$, as well as in metatranscriptomic datasets from soybean leaves and arthropods ${ }^{36,56-60}$. Currently there are nine classified species in two genera in family Mymonaviridae (2019.001F.R.Hubramonavirus_1gen at https://talk.ictvonline.org/files/). However, a recent proposal accepted by the ICTV Executive Committee (2020.004F.Ac.v1.Mymona) suggests 
the introduction of seven more genera in the family, including the genus Lentimonavirus where the newly characterized AmNSRV1 also groups based on phylogenetic analysis. AmNSRV2 was more closely associated with the genus Auriculariamonavirus. The elongated viral particles discovered earlier in North American strains of pathogenic A. ostoyae isolates seem to be at least $600-800 \mathrm{~nm}$ in length, and resemble those of mymonaviruses ${ }^{31}$.

It was notable that two $A$. mellea isolates from Cape Town were different in their viral composition, although both represent the same introduced pathogen of European origin. Strain CMW3973 isolated in 1996 from Quercus robur in the Company Gardens hosted a mymonavirus and a botourmiavirus, whereas isolate CMW50256 isolated in 2015 from Leucadendron conocarpodendron in the Kirstenbosch National Botanical Garden hosted another putative species of Botourmiaviridae. The two botourmiaviruses shared only ca. $20 \%$ aa sequence identity, therefore indicating that they are separate infections. Isolate CMW3973 represents A. mellea genotype A2 and isolate CMW50256 genotype $\mathrm{A}^{9}$, which are somatically compatible. It is considered that these closely related genotypes originate from a single introduction event of the pathogen into South Africa in the $1600 \mathrm{~s}^{8}$.

Ambi-like viruses were found to be very common in isolates of Armillaria and occurred in almost all isolates from the Northern hemisphere. "Ambiviruses" constitute a new group of putative viruses that was recently identified by HTS in endomycorrhizal fungi ${ }^{28}$ as well as in Cryphonectria parasitica and Rhizoctonia solani ${ }^{29}$. Based on our ongoing investigations this virus group seems to be very common among asco- and basidiomycetes, but so far there is no information on their morphology, biology or population structure. The virus-like particles described by Blattný et al. ${ }^{30}$ in A. mellea strains from the Czech Republic were described as either rod-shaped $(22-28 \times 119 \mathrm{~nm})$ or isometric $(30 \mathrm{~nm})$. As botourmiaviruses are capsidless, these two viral particle types suggest the presence of a yet uncharacterized virus group, but at this point we cannot verify whether one of them represents "ambiviruses". Moreover, Blattný and colleagues considered their results preliminary as no negative staining was performed. Very similar viral strains occurred in A. borealis isolates from two different sites in Finland as well as Siberia, and only one A. borealis isolate (Ab3B) was free of ambivirus infections. All three ambivirus types co-infected the Siberian A. borealis isolate N40 and the Finnish A. borealis isolate Ab9A. Furthermore, AsAlV3 occurred in one strain of $A$. cepistipes in addition to these two A. borealis isolates. Interestingly, the sequence identity of the AsAlV3 strain from A. cepistipes and A. borealis from Finland was lower than that between the two $A$. borealis strains originating far from each other, suggesting that the ambivirus population might have differentiated based on its host species. However, further studies are needed to decipher whether the Armillaria viruses are species-specific. The Finnish $A$. borealis isolates infected with ambiviruses were all somatically incompatible and were therefore deemed to represent different clonal individuals, although their collection sites were relatively closely located in Southern Finland. Korhonen ${ }^{61}$ reported that the clone size of $A$. borealis (at that time designated as "species A") was 120-150 m in diameter, and suggested their age to be about 100 years.

In this study, we were able to cure the Armillaria isolates from viruses and made a pilot growth experiment to investigate the possibility that viruses could affect the phenotype of their host. No major growth differences were observed between the virus-free and virus-infected isogenic strains, but it should be noted that the laboratory growth rate of virus-infected fungal strains is not necessarily reduced even if they have a lower virulence in natural conditions ${ }^{62}$. Moreover, mycovirus effects have been shown to be dependent on environmental and ecological conditions, such as temperature and fungal competitors present in the substrate ${ }^{63,64}$, and infections by multiple co-infecting viruses may have a different phenotypic outcome than single virus infections ${ }^{65}$. Future studies should determine whether viral infections are transmitted to Armillaria basidiospores and if they are present in actively growing hyphal tips. In this study, the virus-infected fungal isolates originated from fruiting body tissue (Finnish isolates), from wood (Siberian A. borealis) or from diploid mycelia from rhizomorphs, mycelial fans or A. mellea mycelium growing on the roots and root collars (South African isolates). This shows that the viruses are carried into different types of mycelia of Armillaria, and potentially have a possibility to spread into the mycelial network formed by large clonal individuals.

\section{Methods}

Origin and culturing conditions of the Armillaria isolates. A total of 18 Armillaria sp. strains were isolated from fruiting body tissue samples collected mostly from Southern Finland in September 2017 (see Supplementary Table S1 online). In addition, A. borealis strains from Siberia and A. mellea and A. gallica strains from South Africa were obtained from the culture collection (CMW) of Forestry and Agricultural Biotechnology Institute (FABI) and V.N. Sukachev Institute (Supplementary Table S1).

The species determination of the Finnish Armillaria strains was based on fruitbody morphology as well as molecular characterization of the Tef-1a gene region with primer pair EF595F/EF1160R or IGS rDNA with primer pair LR12R/O-1 ${ }^{66-68}$. The A. borealis isolates originating from closely located sampling sites in Southern Finland (see Supplementary Table S1 online) were incubated as dual cultures to decipher whether they represented the same clonal individual based on somatic compatibility as described by Korhonen ${ }^{61}$. Approximate distance between the collection sites was as follows: $17 \mathrm{~m}$ between Ab3 and Ab4; $150 \mathrm{~m}$ between Ab2 and Ab9; $770 \mathrm{~m}$ between Ab3/Ab4 and Ab9; $780 \mathrm{~m}$ between Ab3/Ab4 and Ab2 (see Supplementary Table S1 for the CMW numbers). Isolates $\mathrm{Ab} 3$ and $\mathrm{Ab} 4$ were somatically compatible whereas the other isolates were not.

Virus screening by cellulose chromatography. The Armillaria spp. culture collection was screened for dsRNA viruses using the cellulose chromatography method ${ }^{69,70}$. Briefly, the isolates were grown on liquid medium containing $2 \%$ malt and $1.5 \%$ yeast extract for $2-4$ weeks, and ca. $2 \mathrm{~g}$ of mycelia were harvested and homogenized in a lysis buffer, followed by phenol and chloroform extractions and specific precipitation of dsRNA using Sigma cellulose fibres (medium) in 15\% ethanol concentration. The presence and size of dsRNA was estimated by agarose gel electrophoresis. A virus-infected Heterobasidion isolate (H. parviporum 7R18 or 
RT3.49C hosting the partitivirus HetPV2-pal or HetPV4-pal, respectively ${ }^{71}$ was included in each assay as a control. The isolates used for screening included 9 strains of $A$. borealis from Russia; 16 and 6 strains of $A$. borealis and A. cepistipes from Finland, and 29 strains of A. mellea and 3 strains of A. gallica from South Africa (see Supplementary Table S1 online).

Total RNA extraction and HTS. For the extraction of total RNA, Armillaria mycelia was freeze-dried for $72 \mathrm{~h}$ prior to homogenization in liquid nitrogen. Total RNA was extracted using Spectrum Plant Total RNA Kit (Sigma-Aldrich) as described earlier ${ }^{28}$. RNA quality and quantity was determined using NanoDrop (Thermo Scientific) and by analysing an aliquot of each RNA by an agarose gel electrophoresis.

An RNA-Seq library was constructed using pooled RNA samples from nine Armillaria strains: N40, CMW3973, CMW50256, Ab2B, Ab3B, Ab4B, Ab9A, Al65A and MUS36. The RNA pool included $1 \mu \mathrm{g}$ of total RNA from each fungal strain, except for strain N40 that was represented by two separate RNA extractions $(2 \mu \mathrm{g})$. The RNA pool was sent in ethanol precipitation to Macrogen Korea for further quality determination, library construction and HTS. The library was generated using TruSeq Stranded Total RNA Library prep kit with Human/Mouse/Rat Gold for rRNA removal (Illumina) and 101 bp paired-end reads were obtained using Novaseq (Illumina).

Bioinformatics and in silico mining of virus sequences from transcriptomic data. The raw reads were preprocessed with Trimmomatic ${ }^{72}$ and de novo assembly was conducted using Trinity (version 2.8.4 or 2.8.5) ${ }^{73}$ in $\mathrm{R}^{74}$. Host-specific contigs were determined with a Blastx run (e-value 10e-6) using a custom Armillaria protein database (db), generated by combining the A. solidipes, A. gallica and A. ostoyae protein models ${ }^{75}$. Contigs showing significant Blastx similarity with Armillaria protein models were omitted and a subsequent Blastx run (e-value 10e-3) was performed against a custom viral protein $\mathrm{db}$. Contigs longer than $500 \mathrm{nt}$ and resembling viral proteins were then re-examined using Blastn and Blastx searches against complete nucleotide and non-redundant protein sequences. Geneious 10.2.6 (Biomatters Ltd) was used for further analysis of the putative virus contigs and mapping of reads. Additionally, fifteen publicly available RNA-Seq libraries representing 13 different Armillaria species (see Supplementary Table S4 online) were analysed for the presence of RNA viruses using the same bioinformatics pipeline. The genome drafts of the Armillaria strains hosting putative mycoviruses were analysed with Blastn to confirm the putative viruses were not detected in the host DNA (see Supplementary Table S8 online).

In order to determine putative ORFans in the Armillaria library, Trinity contigs (not showing similarity with Armillaria or putative viral contigs) $\geq 1500 \mathrm{nt}$ in length, having ORF $\geq 400 \mathrm{nt}$ were selected and examined with Blastn, Blastp and Blastx searches against complete nucleotide and non-redundant protein sequences. Finally, the raw reads of the Armillaria library were mapped against contigs with no hits (see Supplementary Table S3 online).

Validation of virus-like contigs. A 2 - $\mu \mathrm{g}$ sample of each total RNA included in the RNA pool was converted to cDNA using RevertAid Reverse Trancriptase (Thermo Fisher Scientific) and random hexamer primers. Determination of host strains was performed using RT-PCR with DreamTaq DNA Polymerase (Thermo Fisher Scientific) and virus-specific primers (see Supplementary Table S9 online).

To investigate the possibility of genomic integration of the viral sequences, two nucleic acid extractions were performed for Armillaria strains N40, MUS36, CMW3973, CMW50256, and Al65A. Total nucleic acids were extracted using a modified phenol-chloroform extraction method described by Vainio et al. ${ }^{76}$ and DNA using the E.Z.N.A Forensic DNA Kit (Omega Bio-tek). Diluted nucleic acid samples were used as templates in standard PCR with DreamTaq DNA Polymerase and virus-specific primers (the same as used for host screening). The quality of DNA was verified by using it as a template for PCR amplification of ITS rDNA and M13 minisatellite markers $^{77}$ as described earlier ${ }^{78}$. Putative virus contigs DN471, DN562 and DN2538 were confirmed to occur in more than one Armillaria strain. For contig DN471 genomic integration was tested using DNA of N40. DNA of N40 and DNA of MUS36 were used in testing the integration of contig DN562 and DNA of N40 and DNA of Al65A for DN2538.

Determination of complete virus genome sequences. The single primer amplification technique of Lambden et al. ${ }^{79}$ was used for attempts to determine the viral $5^{\prime}$ and 3 ' UTRs. The T4 adapter or primer A blocked at the $3^{\prime}$ end by an $\mathrm{NH}_{2}$ group ${ }^{80,81}$ was ligated to viral dsRNA or total RNA using the T4 RNA ligase (Thermo Fisher Scientific), followed by purification of RNA by agarose gel electrophoresis and extraction using the RNAid kit (Bio101, Carlsbad) and reverse transcription. Initial denaturation was conducted for 3-6 min at $99^{\circ} \mathrm{C}$, and reverse transcription $\left(1 \mathrm{~h} 30 \mathrm{~min}\right.$ ) at $55^{\circ} \mathrm{C}, 60^{\circ} \mathrm{C}$ and $50^{\circ} \mathrm{C}$ for Maxima $\mathrm{H}$ Minus Reverse Transcriptase (Thermo Fisher Scientific), SuperScript IV (Invitrogen) and RevertAid H minus Reverse Transcriptase (Thermo Fisher Scientific), respectively. Phusion High-Fidelity DNA Polymerase (Thermo Fisher Scientific) was used for PCRs together with a primer complementary to the T4 RNA adapter or primer A and a virus specific primer (Supplementary Table S9). Each sequence position was characterized by analysing at least two Sanger sequences determined at Macrogen Europe. The complete sequences of putative viral contigs showing similarity to genomes of ambiviruses were determined from all A. borealis and A. cepistipes hosts (Table 1) using Phusion High-Fidelity DNA Polymerase and virus specific primers (see Supplementary Table S9 online).

Virus curing and growth rate measurements. Armillaria strains N40, CMW3973, CMW50256, Al65A and $\mathrm{Ab} 9 \mathrm{~A}$ were grown on $2 \% \mathrm{MEA}$ plates at RT prior to the initiation of thermal treatments. The plates were first incubated for a week at $32{ }^{\circ} \mathrm{C}$ in the dark where after the temperature was risen gradually every week up to $38^{\circ} \mathrm{C}$ until the mycelial growth halted. The growth of the cultures was investigated weekly and after the final incuba- 
tion, the fungal cultures were recovered on 2\% MEA plates in RT for 9 days. RNA was extracted from mycelia with Spectrum Plant Total RNA Kit and the presence of mycoviruses was analysed with RT-PCR as described above. In order to validate the cDNA synthesis, the same templates were used for the amplification of hostderived marker molecules. The primer pair ITS1-F/ITS4 was used for the amplification of ITS rDNA ${ }^{82,83}$, and the primer pair for EF595F/EF1160R the amplification of Tef-1a. The total RNA extracts used as templates were treated with DNase I (Thermo) to prevent amplification from DNA templates. The same RNA extract without DNase treatment yielded ITS rDNA/Tef-1a amplification products, whereas the DNase-treated template without reverse transcription did not, hence validating the functionality of the DNase treatment.

The growth rates of isogenic virus infected and cured (virus-free) Armillaria strains were compared by inoculating each fungal strain on 2\% MEA plates and recording their growth during three weeks at room temperature $\left(20^{\circ} \mathrm{C}\right)$ in the dark. The inoculum was an agar piece of $0.5 \mathrm{~mm}$ in diameter from the actively growing part of the mycelium. There were six replicate cultures for each fungal strain. The ImageJ program of the Fiji Platform ${ }^{84}$ was used to measure the area of mycelial growth, and the statistical difference between isogenic virus-infected and virus-free fungal strains was tested using t-test in Microsoft Excel 2016 (two sample assuming unequal variances).

\section{Data availability}

Nucleotide sequence data reported are available in the GenBank database under the accession numbers MW423800-13 and TPA: BK014417-22, and the RNA-Seq reads are deposited in the SRA and can be accessed through PRJNA685612. The datasets generated during and/or analysed during the current study are available in the NCBI SRA repository under the BioProject numbers listed in Table 1.

Received: 15 January 2021; Accepted: 10 March 2021

Published online: 01 April 2021

\section{References}

1. Coetzee, M., Wingfield, B. D. \& Wingfield, M. J. Armillaria root-rot pathogens: Species boundaries and global distribution. Pathogens 7, 83. https://doi.org/10.3390/pathogens7040083 (2018).

2. Baumgartner, K., Coetzee, M. \& Hoffmeister, D. Secrets of the subterranean pathosystem of Armillaria. Mol. Plant Pathol. 12, 515-534 (2011).

3. Smith, M. L., Bruhn, J. N. \& Anderson, J. B. The fungus Armillaria bulbosa is among the largest and oldest organisms. Nature 356, 428-431 (1992).

4. Ferguson, B. A., Dreisbach, T. A., Parks, C. G., Filip, G. M. \& Schmitt, C. L. Coarse-scale population structure of pathogenic Armillaria species in a mixed-conifer forest in the Blue Mountains of northeast Oregon. Can. J. For. Res. 33, 612-623 (2003).

5. Coetzee, M. P. A., Bloomer, P., Wingfield, M. J. \& Wingfield, B. D. Paleogene radiation of a plant pathogenic mushroom. PLoS ONE 6, e28545. https://doi.org/10.1371/journal.pone.0028545 (2011).

6. Anderson, J. B. et al. Clonal evolution and genome stability in a 2500-year-old fungal individual. Proc. R. Soc. B 285, 20182233. https://doi.org/10.1098/rspb.2018.2233 (2018).

7. Guillaumin, J.-J. et al. Geographical distribution and ecology of the Armillaria species in western Europe. Eur. J. Plant Pathol. 23, 321-341 (1993).

8. Coetzee, M. P. A. et al. The root rot fungus Armillaria mellea introduced into South Africa by early Dutch settlers. Mol. Ecol. 10, $387-396$ (2001).

9. Coetzee, M. P. A. et al. Armillaria root rot spreading into a natural woody ecosystem in South Africa. Plant Pathol. 67, 883-891 (2018).

10. Guillaumin, J.-J., Mohammed, C. \& Berthelay, S. Armillaria species in the northern temperate hemisphere in Proceedings of the Seventh International Conference on Root and Butt Rots (ed. Morrison, D. J.) 27-43 (Forestry Canada, 1989).

11. Harrington, T. C. \& Rizzo, D. M. Identification of Armillaria species from New Hampshire. Mycologia 85, 365-368 (1993).

12. Ota, Y. et al. Biological species of Armillaria in Japan. Plant Dis. 82, 537-543 (1998).

13. Cleary, M. R. et al. Stump removal to control root disease in Canada and Scandinavia: A synthesis of results from long-term trial. For. Ecol. Manag. 290, 5-14 (2013).

14. Ghabrial, S. A., Caston, J. R., Jiang, D., Nibert, M. L. \& Suzuki, N. 50-plus years of fungal viruses. Virology 479-480, 356-368 (2015).

15. Hillman, B. I., Aulia, A. \& Suzuki, N. Viruses of plant-interacting fungi. Adv. Virus Res. 100, 99-116 (2018).

16. Sutela, S., Poimala, A. \& Vainio, E. J. Viruses of fungi and oomycetes in the soil environment. FEMS Microbiol. Ecol. 95, 119. https:// doi.org/10.1093/femsec/fiz119 (2019).

17. Myers, J. M. et al. Survey of early-diverging lineages of fungi reveals abundant and diverse mycoviruses. mBio 11, e02027. https:// doi.org/10.1128/mBio.02027-20 (2020).

18. Hollings, M. Viruses associated with die-back disease of cultivated mushrooms. Nature 196, 962-965 (1962).

19. Stielow, B. \& Menzel, W. Complete nucleotide sequence of TaV1, a novel totivirus isolated from a black truffle ascocarp (Tuber aestivum Vittad.). Arch. Virol. 155, 2075-2078 (2010).

20. Lin, Y. H. et al. Two novel fungal negative-strand RNA viruses related to mymonaviruses and phenuiviruses in the shiitake mushroom (Lentinula edodes). Virology 533, 125-136 (2019).

21. Vainio, E. J. \& Hantula, J. Taxonomy, biogeography and importance of Heterobasidion viruses. Virus Res. 219, 2-10 (2016).

22. Suzuki, N. Frontiers in fungal virology. J. Gen. Plant Pathol. 83, 419-423 (2017).

23. Vainio, E. J. Mitoviruses in the conifer root rot pathogens Heterobasidion annosum and H. parviporum. Virus Res. $271,197681$. https://doi.org/10.1016/j.virusres.2019.197681 (2019).

24. Milgroom, M. G. \& Cortesi, P. Biological control of chestnut blight with hypovirulence: A critical analysis. Annu. Rev. Phytopathol. 42, 311-338 (2004).

25. Rigling, D. \& Prospero, S. Cryphonectria parasitica, the causal agent of chestnut blight: Invasion history, population biology and disease control. Mol. Plant Pathol. 19, 7-20 (2018).

26. Jiāng, D., Ayllón, M. A., Marzano, S. L. \& ICTV Report Consortium. ICTV virus taxonomy profile: Mymonaviridae. J. Gen. Virol. 100, 1343-1344 (2019)

27. Ayllón, M. A. et al. ICTV virus taxonomy profile: Botourmiaviridae. J. Gen. Virol. 101, 454-455 (2020).

28. Sutela, S. et al. The virome from a collection of endomycorrhizal fungi reveals new viral taxa with unprecedented genome organization. Virus Evol. 6, 76. https://doi.org/10.1093/ve/veaa076 (2020). 
29. Forgia, M., Isgandarli, E., Aghayeva, D. N., Huseynova, I. \& Turina, M. Virome characterization of Cryphonectria parasitica isolates from Azerbaijan unveiled a new mymonavirus and a putative new RNA virus unrelated to described viral sequences. Virology 553 , 51-61 (2021).

30. Blattný, C., Králík, O., Veselský, J., Kasala, B. \& Herzová, H. Particles resembling virions accompanying the proliferation of Agaric mushrooms. Česká Mykologie 27, 1-5 (1973).

31. Reaves, J. L., Allen, T. C., Shaw, C. G., Dashek, W. V. \& Mayfield, J. E. Occurrence of viruslike particles in isolates of Armillaria. J. Ultrastruct. Mol. Struct. Res. 98, 217-221 (1988).

32. Li, X. et al. Molecular characteristics of a novel ssRNA virus isolated from Auricularia heimuer in China. Arch. Virol. 165, 1495-1499 (2020).

33. Wang, M. et al. Characterization of a novel megabirnavirus from Sclerotinia sclerotiorum reveals horizontal gene transfer from single-stranded RNA virus to double-stranded RNA virus. J. Virol. 89, 8567-8579 (2015).

34. Vainio, E. J. \& Sutela, S. Mixed infection by a partitivirus and a negative-sense RNA virus related to mymonaviruses in the polypore fungus Bondarzewia berkeleyi. Virus Res. 286, 198079. https://doi.org/10.1016/j.virusres.2020.198079 (2020).

35. Deakin, G. et al. Multiple viral infections in Agaricus bisporus-Characterisation of 18 unique RNA viruses and 8 ORFans identified by deep sequencing. Sci. Rep. 7, 2469. https://doi.org/10.1038/s41598-017-01592-9 (2017).

36. Marzano, S. Y. L. et al. Identification of diverse mycoviruses through metatranscriptomics characterization of the viromes of five major fungal plant pathogens. J. Virol. 90, 6846-6863 (2016).

37. Picarelli, M. A. S. C. et al. Extreme diversity of mycoviruses present in isolates of Rhizoctonia solani AG2-2 LP from Zoysia japonica from Brazil. Front. Cell. Infect. Microbiol. 9, 244. https://doi.org/10.3389/fcimb.2019.00244 (2019).

38. Yaegashi, H. et al. Appearance of mycovirus-like double-stranded RNAs in the white root rot fungus, Rosellinia necatrix, in an apple orchard. FEMS Microbiol. Ecol. 83, 49-62 (2013).

39. Vainio, E. J., Müller, M. M., Korhonen, K., Piri, T. \& Hantula, J. Viruses accumulate in aging infection centers of a fungal forest pathogen. ISME J. 9, 497-507 (2015).

40. Yaegashi, H. \& Kanematsu, S. Natural infection of the soil-borne fungus Rosellinia necatrix with novel mycoviruses under greenhouse conditions. Virus Res. 219, 83-91 (2016).

41. Vainio, E. J., Pennanen, T., Rajala, T. \& Hantula, J. Occurrence of similar mycoviruses in pathogenic, saprotrophic and mycorrhizal fungi inhabiting the same forest stand. FEMS Microbiol. Ecol. 93, 3. https://doi.org/10.1093/femsec/fix003 (2017).

42. Arjona-Lopez, J. M. et al. Novel, diverse RNA viruses from Mediterranean isolates of the phytopathogenic fungus, Rosellinia necatrix: insights into evolutionary biology of fungal viruses. Environ. Microbiol. 20, 1464-1483 (2018).

43. Dvořák, J. Výskyt RNA elementů u rodu Armillaria. 2008. Diplomová práce. Univerzita Karlova, Př́rodovědecká fakulta, Katedra genetiky a mikrobiologie. "RNA elements in the genus Armillaria" Diploma thesis (2008) [In Czech]. Permanent link: http://hdl. handle.net/20.500.11956/1281

44. Adams, M. J. et al. ICTV virus taxonomy profile: Virgaviridae. J. Gen. Virol. 98, 1999-2000 (2017).

45. Pandey, B., Naidu, R. A. \& Grove, G. G. Next generation sequencing analysis of double-stranded RNAs from sweet cherry powdery mildew fungus Podosphaera prunicola. J. Plant Pathol. 100, 435-446 (2018).

46. Chiapello, M., Rodriguez-Romero, J., Ayllon, M. A. \& Turina, M. Analysis of the virome associated to grapevine downy mildew lesions reveals new mycovirus lineages. Virus Evol. 6, 58. https://doi.org/10.1093/ve/veaa058 (2020).

47. Gilbert, K. B., Holcomb, E. E., Allscheid, R. L. \& Carrington, J. C. Hiding in plain sight: New virus genomes discovered via a systematic analysis of fungal public transcriptomes. PLoS ONE 14, e0219207. https://doi.org/10.1371/journal.pone.0219207 (2019).

48. Chiba, Y., Oiki, S., Yaguchi, T., Urayama, S. I. \& Hagiwara, D. Discovery of divided RdRp sequences and a hitherto unknown genomic complexity in fungal viruses. Virus Evol. 7, 101. https://doi.org/10.1093/ve/veaa101 (2021).

49. Koonin, E. V. \& Dolja, V. V. Virus world as an evolutionary network of viruses and capsidless selfish elements. Microbiol. Mol. Biol. Rev. 78, 278-303 (2014).

50. Howitt, R. L. J., Beever, R. E., Pearson, M. N. \& Forster, R. L. S. Genome characterization of Botrytis virus F, a flexuous rod-shaped mycovirus resembling plant 'potex-like' viruses. J. Gen. Virol. 82, 67-78 (2001).

51. Xie, J. et al. Characterization of debilitation-associated mycovirus infecting the plant-pathogenic fungus Sclerotinia sclerotiorum. J. Gen. Virol. 87, 241-249 (2006).

52. Liu, H. et al. A novel mycovirus that is related to the human pathogen hepatitis E virus and rubi-like viruses. J. Virol. 83, 1981-1991 (2009).

53. Turina, M. et al. ICTV virus taxonomy profile: Ourmiavirus. J. Gen. Virol. 98, 129-130 (2017).

54. Rastgou, M. et al. Molecular characterization of the plant virus genus Ourmiavirus and evidence of inter-kingdom reassortment of viral genome segments as its possible route of origin. J. Gen. Virol. 90, 2525-2535 (2009).

55. Simmonds, P. et al. Virus taxonomy in the age of metagenomics. Nat. Rev. Microbiol. 15, 161-168 (2017).

56. Liu, L. et al. Fungal negative-stranded RNA virus that is related to bornaviruses and nyaviruses. Proc. Natl. Acad. Sci. U.S.A. 111, 12205-12210 (2014).

57. Marzano, S. Y. L. \& Domier, L. L. Novel mycoviruses discovered from metatranscriptomics survey of soybean phyllosphere phytobiomes. Virus Res. 213, 332-342 (2016).

58. Shi, M. et al. Redefining the invertebrate RNA virosphere. Nature 540, 539-543 (2016).

59. Mu, F. et al. Virome characterization of a collection of S. sclerotiorum from Australia. Front. Microbiol. 11, 2540. https://doi.org/ 10.3389/fmicb.2017.02540 (2018).

60. Wang, L. et al. Evidence for a novel negative-stranded RNA mycovirus isolated from the plant pathogenic fungus Fusarium graminearum. Virology 518, 232-240 (2018).

61. Korhonen, K. Interfertility and clonal size in the Armillariella mellea complex. Karstenia 18, 31-42 (1978).

62. Bryner, S. F. \& Rigling, D. Temperature-dependent genotype-by genotype interaction between a pathogenic fungus and its hyperparasitic virus. Am. Nat. 177, 65-74 (2011).

63. Hyder, R. et al. Two viruses of Heterobasidion confer beneficial, cryptic or detrimental effects to their hosts in different situations. Fungal Ecol. 6, 387-396 (2013).

64. Vainio, E. J., Piri, T. \& Hantula, J. Virus community dynamics in the conifer pathogenic fungus Heterobasidion parviporum following an artificial introduction of a partitivirus. Microb. Ecol. 65, 28-38 (2013).

65. Hantula, J. et al. Multiple virus infections of Heterobasidion sp. Fungal Biol. 124, 102-109 (2020).

66. Veldman, G. M. et al. The primary and secondary structure of yeast 26S rRNA. Nucleic Acids Res. 9, 6935-6952 (1981).

67. Duchesne, L. C. \& Anderson, J. B. Location and direction of transcription of the 5S rRNA gene in Armillaria. Mycol. Res. 94, 266-269 (1990).

68. Kauserud, H. \& Schumacher, T. Outcrossing or inbreeding: DNA markers provide evidence for type of reproductive mode in Phellinus nigrolimitatus (Basidiomycota). Mycol. Res. 105, 676-683 (2001).

69. Morris, T. J. \& Dodds, J. A. Isolation and analysis of double-stranded RNA from virus-infected plant and fungal tissue. Phytopathology 69, 854-858 (1979).

70. Tuomivirta, T. \& Hantula, J. Two unrelated double-stranded RNA molecule patterns in Gremmeniella abietina type A code for putative viruses of the families Totiviridae and Partitiviridae. Arch. Virol. 148, 2293-2305 (2003).

71. Vainio, E. J., Hakanpää, J., Dai, Y.-C., Hansen, E. \& Hantula, J. Species of Heterobasidion host a diverse pool of partitiviruses with global distribution and interspecies transmission. Fungal Biol. 115, 1234-1243 (2011). 
72. Bolger, A. M., Lohse, M. \& Usadel, B. Trimmomatic: A flexible trimmer for Illumina sequence data. Bioinformatics 30, 2114-2120 (2014).

73. Grabherr, M. G. et al. Full-length transcriptome assembly from RNA-Seq data without a reference genome. Nat. Biotechnol. 29, 644-652 (2011).

74. R Development Core Team R: A language and environment for statistical computing (R foundation for statistical computing, 2011).

75. Sipos, G. et al. Genome expansion and lineage-specific genetic innovations in the forest pathogenic fungi Armillaria. Nat. Ecol. Evol. 1, 1931-1941 (2017).

76. Vainio, E. J., Korhonen, K. \& Hantula, J. Genetic variation in Phlebiopsis gigantea as detected with random amplified microsatellite (RAMS) markers. Mycol. Res. 102, 187-192 (1998).

77. Stenlid, J., Karlsson, J. O. \& Högberg, N. Intraspecific genetic variation in Heterobasidion annosum revealed by amplification of minisatellite DNA. Mycol. Res. 98, 57-63 (1994).

78. Vainio, E. J., Lipponen, K. \& Hantula, J. Persistence of a biocontrol strain of Phlebiopsis gigantea in conifer stumps and its effects on within-species genetic diversity. For. Path. 32, 285-295 (2001).

79. Lambden, P. R., Cooke, S. J., Caul, E. O. \& Clarke, I. N. Cloning of noncultivatable human rotavirus by single primer amplification. J. Virol. 66, 1817-1822 (1992).

80. Attoui, H. et al. Strategies for the sequence determination of viral dsRNA genomes. J. Virol. Methods. 89, 147-158 (2000).

81. Tuomivirta, T. T. \& Hantula, J. Gremmeniella abietina mitochondrial RNA virus S1 is phylogenetically related to the members of the genus Mitovirus. Arch. Virol. 148, 2429-2436 (2003).

82. White, T. J., Bruns, T., Lee, S. \& Taylor, J. W. Amplification and direct sequencing of fungal ribosomal RNA genes for phylogenetics in PCR protocols-a guide to methods and applications (eds. Innis, M. A., Gelfand, D. H., Sninsky, J. J. \& White, T. J.) 315-322 (Academic Press, 1990).

83. Gardes, M. \& Bruns, T. D. ITS primers with enhanced specificity for basidiomycetes-application to the identification of mycorrhizae and rusts. Mol. Ecol. 2, 113-118 (1993).

84. Schindelin, J. et al. Fiji: An open-source platform for biological-image analysis. Nat. Methods 9, 676-682 (2012).

85. Tsai, C. C. et al. Comparative transcriptome analysis of Gastrodia elata (Orchidaceae) in response to fungus symbiosis to identify gastrodin biosynthesis-related genes. BMC Genom. 17, 212. https://doi.org/10.1186/s12864-016-2508-6 (2016).

86. Kumar, S., Stecher, G., Li, M., Knyaz, C. \& Tamura, K. MEGA X: Molecular evolutionary genetics analysis across computing platforms. Mol. Biol. Evol. 35, 1547-1549 (2018).

87. Trifinopoulos, J., Nguyen, L.-T., von Haeseler, A. \& Minh, B. Q. W-IQ-TREE: A fast online phylogenetic tool for maximum likelihood analysis. Nucleic Acids Res. 44, W232-W235 (2016).

88. Kumar, S., Stecher, G. \& Tamura, K. MEGA7: Molecular evolutionary genetics analysis version 7.0 for bigger datasets. Mol. Biol. Evol. 3, 1870-1874 (2016).

\section{Acknowledgements}

Tuija Hytönen, Alex Nordlund and Runlei Chang are thanked for excellent technical assistance and Pyry Veteli for providing Finnish isolates of Armillaria. The CSC - IT Center for Science, Finland, is acknowledged for providing computational resources. This work was funded by the Academy of Finland (decision number 309896). We are grateful to the 1 KFG project (CSP 1974) for access to unpublished genome data. The genome sequence data were produced by the US Department of Energy Joint Genome Institute in collaboration with the user community, and we acknowledge the JGI team and the people who generated the material and RNA for the project: Francis M. Martin, László Nagy, Neha Sahu, Sara Hortal Botifoll, Johanna Wong-Bajracharya and Jonathan M. Plett.

\section{Author contributions}

E.J.V., R.L., S.S., J.H. and B.W. designed the research; R.L., S.S., E.J.V., M.P.A.C., T.D., I.P., and Y.L. contributed to acquisition, analysis, or interpretation of data; S.S., E.J.V., R.L. and M.P.A.C. drafted the work or substantively revised it.

\section{Competing interests}

The authors declare no competing interests.

\section{Additional information}

Supplementary Information The online version contains supplementary material available at https://doi.org/ 10.1038/s41598-021-86343-7.

Correspondence and requests for materials should be addressed to E.J.V.

Reprints and permissions information is available at www.nature.com/reprints.

Publisher's note Springer Nature remains neutral with regard to jurisdictional claims in published maps and institutional affiliations.

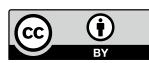

Open Access This article is licensed under a Creative Commons Attribution 4.0 International License, which permits use, sharing, adaptation, distribution and reproduction in any medium or format, as long as you give appropriate credit to the original author(s) and the source, provide a link to the Creative Commons licence, and indicate if changes were made. The images or other third party material in this article are included in the article's Creative Commons licence, unless indicated otherwise in a credit line to the material. If material is not included in the article's Creative Commons licence and your intended use is not permitted by statutory regulation or exceeds the permitted use, you will need to obtain permission directly from the copyright holder. To view a copy of this licence, visit http://creativecommons.org/licenses/by/4.0/.

(C) The Author(s) 2021 